\title{
The Estimation of Genetic Parameters for Body Weight, Body Dimension, and Carcass Traits in Four Egyptian Chickens Strains
}

\author{
Mahmoud Mostafa El-Attrouny ${ }^{1 *}$, Mahmoud Maghraby Iraqi ${ }^{1}$, and Shereen Abdel-Hameed Mohamed ${ }^{2}$ \\ ${ }^{I}$ Department of Animal Production, Faculty of Agriculture at Moshtohor, Benha University, Qalyubia, Egypt \\ ${ }^{2}$ Department of Genetics and Genetic Engineering, Faculty of Agriculture, Benha University, Qalyubia, Egypt \\ *Corresponding author's Email: mahmoud.elatrouny@ fagr.bu.edu.eg; ORCID: 0000-0001-5863-6181
}

Received: 03 Apr. 2021

Accepted: 17 May 2021

\begin{abstract}
Body weight and carcass traits are important traits in the poultry industry. Breeding programs are powerful strategies to improve these economic traits. The challenge, however, is to choose an appropriate strategy to increase production. The estimation of genetic parameters in target strains could provide valuable information to determine the potent breeding strategy. Therefore, the aim of the current study was to assess the heritability and the genetic correlations of the Body Weight (BW), Body Dimensions (BD), and Carcass Traits (CT) in four Egyptian strains (Matrouh, Mandarah, Inshas, and Silver Montazah) of dual-purpose chickens. The BW was measured at hatching (BW0), 8 weeks (BW8), and 16 weeks (BW16) of age, and weight gain was calculated from 8 to 16 weeks of age. The BD traits included shank length (SL), keel length (KL), and Body Circumference (BC). Carcass, liver, gizzard, heart, head, and leg percentages were also determined. Data were collected on 2800 dual-purpose chickens with pedigree information. A Multitrait animal model with a restricted maximum likelihood procedure was applied to estimate heritability, genetic and phenotypic correlations for BW, BD, and CT using Wombat software. Heritability estimates for BW traits were between 0.24 and 0.41 for BW0 and BW8, respectively. Heritability estimates of SL, KL, and BC were $0.49,0.41$, and 0.52 , respectively. The heritability estimates for CT were low to moderate, ranging from 0.15 to 0.37 for head and gizzard percentage, respectively. The least-square means for BW, BD, and CT varied significantly between strains. The genetic correlation estimates among BW and BD traits indicated a close genetic relationship between these traits. Positive genetic correlations were found between BW and BD with CT (from 0.12 to 0.78). Based on the present results, there were strong positive genetic correlations between all traits, including BW and BD as the most important ones. Therefore, the selection for these traits would improve the carcass traits in the four strains of chickens. Hence, the inclusion of BW and BD as selection criteria in breeding programs would potently affect the improvement in carcass performance, which might positively increase the production profit of such strains.
\end{abstract}

Keywords: Body dimensions, Carcass, Egyptian strains, Genetic parameters, Heritability

\section{INTRODUCTION}

Poultry has been considered as one of the main sources of high-quality animal protein (FAO, 2005; Hosny, 2006; Randazzo et al., 2021). Egypt possesses a wide variety of chickens, including indigenous ones, which are characterized by high resistance to various diseases and performing well in harsh environments and nutritional conditions (Hosny, 2006). Despite the fact that Egyptian chickens are valuable native breeds, the information about their genetic variability and relationships is limited (Eltanany et al., 2011; Ramadan et al., 2012; El-Attrouny et al., 2020). Parameters of growth traits had a genetic basis and vary between chicken breeds (Kosba and Abd El-Halim, 2008; Hermiz et al., 2020). The growth rate is a critical trait and could be considered as a direct fitness trait. Evaluating the differences between chicken breeds on growth traits is essential to increase the production efficiency and consequently decreased production costs (Iraqi et al., 2002; El-Attrouny et al., 2017; Chu et al., 2020).

The genetic response of breeding programs depended on estimates of genetic parameters, such as heredity, phenotypic, and genetic correlations between the traits in the breeding goal and the corresponding selection index. To support genetic improvement, it is important to define the breeding objective, production, and breeding systems. Knowledge of the genetic parameters is crucial to accurately estimate the breeding values, optimize the combination of traits in a selection program as well as breeding schemes, and improve the prediction of the 
response to the selection (Prado-Gonzalez et al., 2003; Adeogun and Adeoye, 2004; Norris et al., 2004; Gaya et al., 2011). Accordingly, the lack of information on genetic components of variance and genetic parameters limited genetic improvement. In this context, heritability estimated for Body Dimensions (BD) and Carcass Traits (CT) in chickens varied from medium to high (Chabault et al., 2012; Abou El-Ghar and El-Karim, 2016; Bungsrisawat et al., 2018; Ullengala et al., 2020).

The breeding strategies to improve meat production concentrate on rapid growth and CT. Choosing the specific body weight that corresponds to the market weight is the most common practice among breeders. As a result, the age of selection became progressively earlier as the potential for growth increased (Aslam et al., 2011; Saxena and Kolluri, 2018).

There are two more selection strategies, which are chosen in the commercial age or in a multi-stage selection. Various breeding and selection strategies at different time intervals have been used to improve the genetic components of poultry (Johansson et al., 2010; Ahsan et al., 2013; Jambui et al., 2017). Feed Conversion Ratio (FCR), BD, Carcass Percentage (CP), and meat quality are the major traits in broilers. Moreover, carcass traits are important in determining income from meat production, meaning that the profitability of any enterprise largely depends on the weight and quality of the carcass. Body dimensions have usually been used as an indicator of skeletal development in poultry and could be used to predict carcass yield percentage (Das et al., 2015). Previous studies have shown that selection based on measurement of breast area across the length and width of the breast along with BW resulted in a genetic gain of 277\% per generation (Thiruvenkadan et al., 2011; Saxena and Kolluri, 2018). High and positive correlations between BW and BD were reported in recent studies of Das et al. (2015) and Ullengala et al. (2020). Despite the great importance of such correlations in constructing proper selection indices and consequently performing selection at young ages of chickens, to our knowledge, a few limited studies discussed the genetic and phenotypic correlation among Egyptian strains.

The authors hypothesized that the strain genotype could affect the genetic and phenotypic correlation among economic traits. Therefore, the objective of the present study was to estimate the heritability and the genetic correlation coefficients for $\mathrm{BW}, \mathrm{BD}$, and $\mathrm{CT}$ in four different Egyptian chicken strains. The association between these economic traits in Egyptian chickens could provide useful information in determining a successful breeding strategy.

\section{MATERIALS AND METHODS}

The study was conducted on the Poultry Research Farm, Faculty of Agriculture, Benha University, Egypt. All experimental procedures were approved by the Institutional Animal Care and Use Committee (IACUC) at Benha University.

\section{Ethics approval}

The protocol for the conducted animal experiments was approved by the institutional animal care and use committee (IACUC) of Benha University.

\section{Population structure}

The experiment started in November 2019 and lasted 12 months. Four pedigreed indigenous Egyptian dualpurpose strains of chickens were used in the current study, including Matrouh strain (MT), Mandarah strain (MN), Inshas strain (IN), and Silver Montazah strain (SM).

A total of 2800 chickens were used in this experiment $(n=700$ chickens per strain). The chickens were produced from four strains in a pedigree that mated to 120 sires and 600 dams ( 30 sires and 150 dams for each strain), with each sire was mated to five dams. The eggs were collected daily and labeled according to dam number to identify pedigree information. Before the incubation, the collected eggs were disinfected with formaldehyde and then placed in the incubator for 21 days (18 days in the setter and 3 days in the hatchery). After hatching, chickens were weighed individually and the wings were banded.

\section{Feeding management and diet}

All chickens were from the same hatching batch and subjected to the same feeding management and diet. At one to four weeks of age, chickens were raised with brooders on a litter floor using incandescent lamps, 24hour lights, and no darkness. After four weeks of age, all chickens were placed in a slatted floor barn and fluorescent lighting (20 hours of light and 4 hours of darkness) was arranged up to the 16 weeks of age. Feed and fresh water were provided ad libitum. The diets were formulated to meet the nutritional recommendations for broilers (NRC, 1994). From one day to four weeks of age, all chickens received a starter diet containing $21 \%$ crude protein and $3050 \mathrm{kcal} / \mathrm{kg}$ metabolizable energy. After four weeks up to 16 weeks of age, the chickens were provided 
with grower feed containing $18 \%$ crude protein and 3000 $\mathrm{kcal} / \mathrm{kg}$ metabolizable energy.

\section{Traits}

All chickens were weighed at hatching (BW 0), 8 weeks (BW 8), 16 weeks (BW 16) of age, and the Weight Gain (WG) was calculated at the age of 8 to 16 weeks (WG 8-16). The BW was measured using a digital balance to an accuracy of 0.1-gram.

Body dimensions were measured, including Shank Length, distance from the hock to the extremity of the digitus pedis, keel length, distance from the anterior to the posterior end of the keel; and Breast Circumference (BC: the circumference of the breast around the deepest region of the breast behind the wings through the anterior edge of the keel and middle thoracic vertebra). Measurements were done according to FAO (2012).

To determine carcass characteristics, 600 chickens (n $=150$ per strain) were randomly selected and weighed prior to slaughter based on the average group weight of each strain at 16 weeks of age. Chickens were fasted for a period of 10-hours before slaughter, however, they had unlimited access to water. After slaughter and bleeding, the carcasses were de-feathered and eviscerated (Adeyemi, 2021). The weight of hot carcass, eviscerated, without neck and feet, the edible inner organs (Liver, Gizzard, and Heart), head, and leg were measured after slaughter and as a percentage of live BW expressed.

\section{Statistical analysis}

Descriptive statistics of the performance traits (body weight, body dimension, and carcass traits) were calculated using the UNIVARIATE procedure in the SAS software (SAS, 2004). Differences were considered significant at $p<0.05$ and significant differences between means were tested by Duncan's multiple range test (Duncan, 1955).

The statistical model was $Y_{i j}=\mu+S_{i}+e_{i j}$

Where, $\mathrm{y}_{\mathrm{ij}}$ is the individual observation for each trait, $\mu$ refers to the overall mean, Si denotes the fixed effect of hatching batch with strain $(i=1 \ldots .4)$, and $\mathrm{e}_{\mathrm{ij}}$ signifies the random residual effect $\sim \mathrm{NID}\left(0, \mathrm{~s}^{2} \mathrm{e}\right)$.

The information from the pedigree and performance data was used to estimate the genetic (co) variance components. The fixed effect was genotype and the random effects were additive genetic and residual effects. Variance and covariance components were obtained using the Average Information Restricted Maximum Likelihood method (AI-REML; Johnson and Thompson, 1995) with the WOMBAT software (Meyer, 2012). The mixed linear animal model for multiple traits is shown in the following equation.

$$
\mathrm{y}=\mathrm{Xb}+\mathrm{Zu}+\mathrm{e} \quad \text { Equation } 1
$$

Where, $\mathrm{y}$ is a vector of observing all traits, $\mathrm{b}$ is a vector of the fixed effects made up of strains (4 levels), X represents a design matrix relating the appropriate fixed effects to each trait, $u$ is a vector of the direct genetic effect of trait, $\mathrm{Z}$ is a design matrix relating the appropriate random effect to each individual and $\mathrm{e}$ is a vector of random residual effects.

The mathematical model used in the two-trait analysis is presented in Equation 2.

$\left[\begin{array}{l}y_{1} \\ y_{2}\end{array}\right]=\left[\begin{array}{cc}X_{1} & 0 \\ 0 & X_{2}\end{array}\right]+\left[\begin{array}{l}b_{1} \\ b_{2}\end{array}\right]+\left[\begin{array}{cc}Z_{1} & 0 \\ 0 & Z_{2}\end{array}\right]+\left[\begin{array}{l}a_{1} \\ a_{2}\end{array}\right]+\left[\begin{array}{l}e_{1} \\ e_{2}\end{array}\right]$, Equation 2

Where, $\mathrm{y}_{1}$ and $\mathrm{y}_{2}$ represent different traits. The vectors of fixed effects for trait $1\left(b_{1}\right)$ and trait $2\left(b_{2}\right)$ are the same as described in the univariate model. The vectors $\mathrm{a}_{1}$ and $\mathrm{a}_{2}$ are random additive genetic effects, and $\mathrm{e}_{1}$ and $\mathrm{e}_{2}$ are residual effects for trait1 and trait2, respectively. The incidence matrices $X_{1}$ and $X_{2}$ associated elements of $b_{1}$ and $b_{2}$ with the records in $y_{1}$ and $y_{2}$. The incidence matrices $\mathrm{Z}_{1}$ and $\mathrm{Z} 2$ associate elements of $\mathrm{a}_{1}$ and $\mathrm{a}_{2}$ with the records in $\mathrm{y} 1$ and $\mathrm{y} 2$.

Estimates of heritability were computed from the variance components and (co)variance components were used to calculate genetic correlation and phenotypic correlation using the equation of Falconer and Mackay (1996).

\section{RESULTS AND DISCUSSION}

The descriptive statistics for the studied traits including mean, standard deviation, coefficient of variation, minimum and maximum values, and heritability are presented in Table 1.

\section{Heritability estimates}

The heritability estimates for the traits studied are shown in Table 1 . The heritability estimate for BW8 was greater than the heritability estimates for BW16 (0.41 and 0.30 ), meaning that detecting that genetic variability for BW appeared to be more difficult after 16 weeks of age, compared to 8 weeks of age. Thus, using BW8 as a selection criterion appeared to be more efficient than the use of BW16. The heritability estimates for BW8 and BW16 were similar to those found by Le Bihan-Duval et al. (2001), Iraqi et al. (2002), Resende et al. (2005), and El-Attrouny et al. (2017) and different from those found by Das et al. (2015), and Bungsrisawat et al. (2018). 
Table 1. Descriptive statistics and heritability estimates for body weight (0-16 weeks), and body dimensions, and carcass traits at 16 weeks of age, of four Egyptian dual-purpose chickens (Matrouh, Mandarah, Inshas, and Silver Montazah).

\begin{tabular}{lcccccc}
\hline Items & Mean & SD & CV (\%) & Min & Max & $\mathbf{h}^{2} \pm$ SE \\
\hline Body weight & & & & & & \\
BW0 (g) & 33 & 3.5 & 10.6 & 25 & 41 & $0.24 \pm 0.02$ \\
BW8 (g) & 560 & 104 & 19 & 402 & 753 & $0.41 \pm 0.02$ \\
BW 16 (g) & 1351 & 334 & 25 & 842 & 1820 & $0.30 \pm 0.02$ \\
WG8-16 (g) & 782 & 115 & 15.0 & 511 & 1012 & $0.26 \pm 0.02$ \\
Body dimension & & & & & & \\
SL (cm) & 7.97 & 1.02 & 12.79 & 7 & 9 & $0.49 \pm 0.03$ \\
KL (cm) & 14.75 & 1.49 & 10.10 & 13 & 16 & $0.41 \pm 0.03$ \\
BC (cm) & 26.7 & 2.04 & 7.64 & 25 & 29 & $0.52 \pm 0.03$ \\
Carcass traits & & & & & & \\
CP (\%) & 63.42 & 4.20 & 7.0 & 58.12 & 70.28 & $0.36 \pm 0.03$ \\
LIV (\%) & 2.17 & 0.15 & 6.9 & 1.40 & 2.65 & $0.27 \pm 0.02$ \\
GIZ (\%) & 2.42 & 0.13 & 5.3 & 1.92 & 3.59 & $0.37 \pm 0.03$ \\
HRT (\%) & 0.59 & 0.08 & 13.5 & 0.43 & 0.84 & $0.39 \pm 0.03$ \\
HD (\%) & 3.06 & 0.41 & 13.3 & 3.12 & 4.48 & $0.15 \pm 0.03$ \\
Leg (\%) & 3.10 & 0.25 & 8.06 & 2.73 & 3.53 & $0.33 \pm 0.03$ \\
\hline
\end{tabular}

BW 0, 8, and 16: Body weight at day old, week 8 and week 16, repectively; WG8-16: Weight gain from 8 to 16 weeks; SL: Shank length; KL: Keel length; BC: Breast circumference; CP: Carcass percentage; LIV: liver percentage; GIZ: Gizzard percentage; HRT: Heart percentage; HD: Head percentage; $h^{2}$ : Heritability; BD: Body dimensions; CT: Carcass traits; SD: Standard deviation; Min: Minimum; Max: Maximum; SE: Standard error.

The heritability estimates for BD in the current study ranged from moderate to high. The heritability estimates of the shank length and keel length values were 0.49 and 0.41 , respectively. The current heritability estimates of shank length and keel length values were lower than those reported by Adebambo et al. (2006), Das et al. (2015). However, Singh and Jilani (2005) reported a lower heritability of keel length (0.15) than the current study (0.36). These variations in the results could be related to the statistical model, genetic groups, and the number of chickens used in the study (El-Attrouny et al., 2020).

The heritability estimate for body circumference (0.52) was similar to that reported by Abd El-Karim and Ashour (2014), and higher than that described by Padhi et al. (2015). The moderate heritability estimate for carcass percentage in the present study was 0.36 , which is similar to that reported by Zerehdaran et al. (2004); Grosso et al. (2010), and as an intermediary to that reported by Gaya et al. (2006) and Felício et al. (2013). This indicated that selection based on carcass percentage will result in a high genetic gain for $\mathrm{CT}$.

Considerable direct additive genetic effects seem to exist in the expression of CT based on their heritability estimates. The heritability estimate for the liver was 0.27 , which was similar to the value reported by Gaya et al.
(2006) and Venturini et al. (2014). In contrast, Cahaner and Nitsan (1985) observed higher heritability estimates for the liver $(0.50)$. This suggests that the liver trait would be responsive to the selection. Nevertheless, the heritability estimates for gizzard in the present study (0.37) differed from those reported by Cahaner and Nitsan (1985) and Rance et al. (2002), who observed higher heritability estimates for gizzard of 0.57 and 0.52 , respectively.

The heritability estimate for the heart was 0.39 , suggesting that this trait could respond to selection. This estimate was similar to those described by Gaya et al. (2006) and Salvian et al. (2020) and was within the range of values observed in the literature for this trait from 0.27 (Venturini et al., 2014) to 0.30 (Rance et al., 2002). In the current study, liver, gizzard, and heart traits were not used as a selection criterion. Although, they may be potentially useful if these traits become limiting factors in the physiological integrity of chickens. Thus, the direct selection to modify organ (liver, gizzard, and heart) traits could be efficient if necessary (Venturini et al., 2014).

The heritability estimate obtained for the leg (0.33), was similar to that presented by Le Bihan-Duval et al. (1998); Gaya et al. (2006); Grosso et al. (2010), but lower than those found by Cahaner and Nitsan (1985); Rance et 
al. (2002); Khalid et al. (2012). The heritability estimate for the head was low (0.15). Khalid et al. (2012) estimated the heritability estimate for head to be 0.20 , suggesting that selection, by itself, might not improve this trait.

\section{Least square means}

As shown in Table 2, there was a significant influence of the genotype on $\mathrm{BW}$ and $\mathrm{WG}$ traits of chickens. The SM strain exhibited the highest BW and WG compared to MN, MT, and IN strains through the entire experimental period $(\mathrm{p} \leq 0.05)$. The SM strain had the greatest value of WG8-16 (830 g), followed by MN $(782 \mathrm{~g})$ and IN (774 g), while MT had the lowest value of WG8-16 (755 g). This could be due to the differences in the genetic make-up of the four strains. Similar results were reported by Kosba and Abd El-Halim (2008) and Debes (2017).

The SM strain revealed the highest significant value of BD followed by MN, MT, and IN strain (Table 2). Comparing the four strains, the SM strain surpassed shank length, keel length, and body circumference by $8.5,15.8$, and $28.2 \mathrm{~cm}$, respectively. Identifying relationships between studied traits was very useful in selecting fastgrowing chickens. The least-square means of $\mathrm{BD}$ in the present study were similar to those reported by Abd ElKarim and Ashour (2014), and El-Attrouny et al. (2020).

The MT strain revealed the highest $(\mathrm{p} \leq 0.05)$ value of carcass percentage (68.36\%) compared to the other three strains $(61.78 \%$ for MN, $61.98 \%$ for IN, and $61.57 \%$ for SM strain) as shown in Table 2. A significant difference was recorded between all strains for liver percentage; however, a non-significant difference was recorded for head percentage. The IN and MT strains had a significantly higher percentage $(p \leq 0.05)$ of the gizzard and heart than MN and SM strains. The MT chickens had a significantly higher percentage $(\mathrm{p} \leq 0.05)$ of leg compared to MN, IN, and SM chickens. Rayan et al. (2017) reported that MT strain had a significantly higher carcass percentage $(60.85 \%)$ compared to the SM strain $(57.97 \%)$.

Table 2. Least square means and standard errors for body weight, body dimension, and carcass traits in different strains.

\begin{tabular}{|c|c|c|c|c|c|}
\hline Items & Mandarah & Matrouh & Inshas & Silver Montazah & $p$ value \\
\hline \multicolumn{6}{|l|}{ Body weight } \\
\hline BW0 (g) & $33 \pm 0.13^{b}$ & $32 \pm 0.13^{c}$ & $33 \pm 0.13^{b}$ & $34 \pm 0.13^{\mathrm{a}}$ & $<0.001 * * *$ \\
\hline BW8 (g) & $548 \pm 9.6^{b}$ & $486 \pm 8.7^{\mathrm{c}}$ & $575 \pm 9.1^{\mathrm{b}}$ & $630 \pm 8.4^{\mathrm{a}}$ & $<0.001 * * *$ \\
\hline BW 16 (g) & $1340 \pm 15.8^{\mathrm{c}}$ & $1260 \pm 1.2^{\mathrm{d}}$ & $1380 \pm 12.9^{\mathrm{b}}$ & $1460 \pm 12.9^{\mathrm{a}}$ & $<0.001 * * *$ \\
\hline WG8-16 (g) & $782 \pm 12.3^{\mathrm{b}}$ & $755 \pm 14.2^{\mathrm{c}}$ & $774 \pm 11.2^{\mathrm{b}}$ & $830 \pm 13.5^{\mathrm{a}}$ & $<0.001 * * *$ \\
\hline \multicolumn{6}{|l|}{ Body dimension } \\
\hline $\mathrm{SL}(\mathrm{cm})$ & $7.8 \pm 0.05^{\mathrm{bc}}$ & $8.0 \pm 0.05^{\mathrm{b}}$ & $7.6 \pm 0.05^{\mathrm{c}}$ & $8.5 \pm 0.05^{\mathrm{a}}$ & $<0.001 * * *$ \\
\hline $\mathrm{KL}(\mathrm{cm})$ & $13.8 \pm 1.10^{\mathrm{b}}$ & $15.2 \pm 1.10^{\mathrm{a}}$ & $14.2 \pm 1.10^{\mathrm{b}}$ & $15.8 \pm 1.10^{\mathrm{a}}$ & $<0.001 * * *$ \\
\hline $\mathrm{BC}(\mathrm{cm})$ & $26.4 \pm 2.21^{\mathrm{b}}$ & $26.4 \pm 2.21^{\mathrm{b}}$ & $26.8 \pm 2.21^{\mathrm{b}}$ & $28.2 \pm 2.21^{\mathrm{a}}$ & $<0.017 * *$ \\
\hline \multicolumn{6}{|l|}{ Carcass traits } \\
\hline $\mathrm{CP}(\%)$ & $61.78 \pm 3.21^{\mathrm{b}}$ & $68.36 \pm 3.21^{\mathrm{a}}$ & $61.98 \pm 3.21^{\mathrm{b}}$ & $61.57 \pm 3.21^{\mathrm{b}}$ & $<0.003 * * *$ \\
\hline LIV (\%) & $2.08 \pm 0.05^{\mathrm{b}}$ & $2.01 \pm 0.05^{\mathrm{b}}$ & $2.39 \pm 0.05^{\mathrm{a}}$ & $1.69 \pm 0.05^{\mathrm{c}}$ & $<0.004 * * *$ \\
\hline GIZ (\%) & $2.69 \pm 0.08^{b}$ & $2.97 \pm 0.08^{\mathrm{a}}$ & $2.98 \pm 0.08^{\mathrm{a}}$ & $2.31 \pm 0.08^{\mathrm{bc}}$ & $<0.012 * *$ \\
\hline $\operatorname{HRT}(\%)$ & $0.55 \pm 0.02^{\mathrm{b}}$ & $0.68 \pm 0.02^{\mathrm{a}}$ & $0.62 \pm 0.02^{\mathrm{a}}$ & $0.49 \pm 0.02^{\mathrm{b}}$ & $<0.018 * *$ \\
\hline HD $(\%)$ & $3.63 \pm 0.09$ & $3.55 \pm 0.09$ & $3.71 \pm 0.09$ & $3.52 \pm 0.09$ & $0.5764^{\mathrm{ns}}$ \\
\hline $\operatorname{Leg}(\%)$ & $3.05 \pm 0.07^{\mathrm{b}}$ & $3.36 \pm 0.07^{\mathrm{a}}$ & $3.07 \pm 0.07^{\mathrm{b}}$ & $2.94 \pm 0.07^{\mathrm{b}}$ & $0.030 * * *$ \\
\hline
\end{tabular}

${ }^{\mathrm{a}-\mathrm{d}}$ Means followed by different superscripts within a row differ significantly (p $\left.\leq 0.05\right) . \overline{\mathrm{BW}} 0,8$, and 16: Body weight at day old, week 8 and week 16 , repectively; WG8-16: Weight gain from 8 to 16 weeks; SL: Shank length; KL: Keel length; BC: Breast circumference; CP: Carcass percentage; LIV: liver percentage; GIZ: Gizzard percentage; HRT: Heart percentage; HD: Head percentage; h2: Heritability; BD: Body dimensions; CT: Carcass traits. 


\section{Genetic and phenotypic correlation estimates}

Genetic parameters including genetic and phenotypic correlations for BW and BD are presented in Table 3. The genetic and phenotypic correlations between all BW measures (BW0, BW8, and BW16) were strong and positive, ranging from $\mathrm{rg}=0.35$ to 0.50 and $\mathrm{rp}=0.27$ to 0.38 . These current results are in agreement with the corresponding correlation reported by Niknafs et al. (2012), El-Attrouny et al. (2017), and Tongsiri et al. (2019). Selection for rapid early growth in market age (3545 days) has been the most common approach in broiler chickens breeding programs (Emmerson, 2003). The current results showed that BW at 16 weeks of age was positively correlated to $\mathrm{BW}$ traits from 0 to 8 weeks of age. The genetic correlations were particularly strong (0.50) with certain BW traits with BW8. Since chickens were raised in Egypt for both meat and egg production, 8 weeks selection could be the most suitable approach to improving growth. The genetic correlations for BD (shank length, keel length, and body circumference) were positive and ranged from 0.47 between keel length and body circumference to 0.62 between shank length and keel length (Table 3). Phenotypic correlations between BD were positive and ranged between 0.25 and 0.31 . This was in agreement with the findings of Abd El-Karim and Ashour (2014), who reported a positive and high genetic correlation between BD (shank length, keel length, and body circumference). The estimate of genetic correlation of BD in the current study was lower than that reported by Ige (2013), who indicated that genetic correlation between shank length and keel length was high (0.97), between shank length and body circumference was 0.99 , and between keel length and body circumference was 0.85 in crossbred Fulani Ecotype chickens.

Table 3. Estimates of genetic correlations (above the diagonal) and phenotypic correlations (below the diagonal), with their standard errors (between parentheses), between body weight, weight gain, and body dimension traits

\begin{tabular}{|c|c|c|c|c|c|c|c|}
\hline Items & BW0 & BW8 & BW16 & WG8-16 & SL & KL & BC \\
\hline BW0 & - & $0.41(0.02)$ & $0.35(0.02)$ & $0.25(0.03)$ & $0.31(0.03)$ & $0.32(0.01)$ & $0.30(0.01)$ \\
\hline BW8 & $0.27(0.02)$ & - & $0.50(0.03)$ & $0.31(0.01)$ & $0.36(0.01)$ & $0.37(0.02)$ & $0.40(0.02)$ \\
\hline BW16 & $0.28(0.02)$ & $0.38(0.02)$ & - & $0.38(0.03)$ & $0.64(0.02)$ & $0.56(0.03)$ & $0.62(0.03)$ \\
\hline WG8-16 & $0.21(0.01)$ & $0.15(0.01)$ & $0.22(0.01)$ & - & $0.32(0.01)$ & $0.39(0.03)$ & $0.43(0.03)$ \\
\hline SL & $0.24(0.02)$ & $0.22(0.01)$ & $0.41(0.02)$ & $0.22(0.02)$ & - & $0.62(0.03)$ & $0.51(0.03)$ \\
\hline $\mathrm{KL}$ & $0.11(0.01)$ & $0.19(0.01)$ & $0.29(0.03)$ & $0.19(0.01)$ & $0.31(0.01)$ & - & $0.47(0.02)$ \\
\hline $\mathrm{BC}$ & $0.19(0.01)$ & $0.31(0.02)$ & $0.33(0.03)$ & $0.24(0.02)$ & $0.28(0.02)$ & $0.25(0.02)$ & - \\
\hline
\end{tabular}

BW 0, 8, and 16: Body weight at day old, week 8 and week 16, repectively; WG8-16: Weight gain from 8 to 16 weeks; SL: Shank length; KL: Keel length; BC: Breast circumference.

It is very important to consider the relationship between BD and BW traits as this could be useful as a selection criterion to improve the BW. Traits representing BD (shank length, keel length, and body circumference) appeared to be highly genetically associated with BW (BW0, BW8, and BW16) because the genetic correlation estimates between these traits ranged from 0.30 between BW0 and body circumference to 0.64 between BW16 and shank length as presented in Table 3. The strong genetic correlation suggested that the direct selection for $\mathrm{BD}$ at different ages could bring indirect genetic gains for BW. Similar genetic correlation estimates between these traits were obtained by Haunshi et al. (2012), Rajkumar et al. (2012), and Ullengala et al. (2020).

Ige (2013) reported that the highest values of the genetic correlation between BW8 and keel length (0.98), shank length (0.90), and body circumference $(0.85)$ were obtained in crossbred Fulani Ecotype chickens. Egena et al.(2014) indicated that BW was positively correlated with body length and body girth traits. This suggested that including $\mathrm{BD}$ in the breeding scheme would have a significant effect on improving growth characteristics through favorable genetic correlations (Rajkumar et al., 2012; Padhi et al., 2015). The phenotypic correlations between the BW and BD traits were positive and ranged from 0.11 between BW0 and keel length to 0.41 between BW16 and shank length (Table 3).

The genetic and phenotypic correlation estimates among BW, BD, and CT are presented in Tables 4 and 5 . The genetic correlation estimates between carcass percentage and BW traits indicated an important genetic association between these traits. It was recorded that the increase in the carcass percentage was associated with higher $\mathrm{BW}$, and the higher the $\mathrm{BW}$, the higher the carcass percentage (Venturini et al., 2014). 
Table 4. Estimates of genetic correlations of body weight, weight gain, shank length, keel length, body circumference with carcass traits. All genetic correlation estimates are shown with corresponding standard errors in parenthesis.

\begin{tabular}{lcccccc}
\hline Traits & CP & LIV & GIZ & HRT & HD & Leg \\
\hline BW0 & $0.30(0.02)$ & $0.12(0.02)$ & $0.14(0.03)$ & $0.18(0.02)$ & $0.21(0.03)$ & $0.23(0.03)$ \\
BW8 & $0.45(0.06)$ & $0.29(0.03)$ & $0.26(0.02)$ & $0.24(0.01)$ & $0.38(0.04)$ & $0.44(0.04)$ \\
BW16 & $0.78(0.06)$ & $0.51(0.06)$ & $0.35(0.03)$ & $0.60(0.05)$ & $0.32(0.02)$ & $0.68(0.04)$ \\
WG8-16 & $0.24(0.03)$ & $0.32(0.03)$ & $0.22(0.02)$ & $0.19(0.02)$ & $0.22(0.01)$ & $0.28(0.03)$ \\
SL & $0.46(0.04)$ & $0.29(0.02)$ & $0.30(0.03)$ & $0.32(0.03)$ & $0.27(0.03)$ & $0.47(0.04)$ \\
KL & $0.62(0.06)$ & $0.27(0.02)$ & $0.19(0.02)$ & $0.25(0.02)$ & $0.16(0.02)$ & $0.39(0.03)$ \\
BC & $0.71(0.04)$ & $0.19(0.02)$ & $0.27(0.02)$ & $0.17(0.02)$ & $0.27(0.02)$ & $0.53(0.04)$ \\
\hline
\end{tabular}

BW 0, 8, and 16: Body weight at day old, week 8 and week 16, repectively; WG8-16: Weight gain from 8 to 16 weeks; SL: Shank length; KL: Keel length; BC: Breast circumference; CP: Carcass percentage; LIV: Liver percentage; GIZ: Gizzard percentage; HRT: Heart percentage; HD: Head percentage.

Table 5. Estimates of phenotypic correlations of body weight, weight gain, Shank length, keel length, breast circumference with carcass traits. All genetic correlation estimates are shown with corresponding standard errors in parenthesis

\begin{tabular}{lcccccc}
\hline Traits & CP & LIV & GIZ & HRT & HD & Leg \\
\hline BW0 & $0.11(0.01)$ & $0.08(0.02)$ & $0.07(0.01)$ & $0.11(0.01)$ & $0.07(0.01)$ & $0.16(0.01)$ \\
BW8 & $0.26(0.02)$ & $0.19(0.06)$ & $0.18(0.01)$ & $0.19(0.02)$ & $0.10(0.01)$ & $0.20(0.02)$ \\
BW16 & $0.42(0.03)$ & $0.23(0.02)$ & $0.24(0.02)$ & $0.23(0.01)$ & $0.11(0.01)$ & $0.17(0.01)$ \\
WG8-16 & $0.19(0.01)$ & $0.22(0.03)$ & $0.16(0.01)$ & $0.12(0.02)$ & $0.13(0.01)$ & $0.15(0.02)$ \\
SL & $0.23(0.02)$ & $0.16(0.01)$ & $0.18(0.01)$ & $0.18(0.01)$ & $0.21(0.02)$ & $0.24(0.02)$ \\
KL & $0.26(0.02)$ & $0.18(0.02)$ & $0.07(0.01)$ & $0.17(0.02)$ & $0.17(0.01)$ & $0.24(0.01)$ \\
BC & $0.30(0.02)$ & $0.09(0.02)$ & $0.19(0.02)$ & $0.09(0.02)$ & $0.16(0.01)$ & $0.31(0.02)$ \\
\hline
\end{tabular}

BW 0, 8, and 16: Body weight at day old, week 8 and week 16, repectively; WG8-16: Weight gain from 8 to 16 weeks; SL: Shank length; KL: Keel length; BC: Breast circumference; CP: Carcass percentage; LIV: Liver percentage; GIZ: Gizzard percentage; HRT: Heart percentage; HD: Head percentage.

The estimates were positive and moderate to high, 0.30 between carcass percentage and BW0; 0.45 between carcass percentage and BW8; and 0.78 between carcass percentage and BW16 (Table 4). Similar genetic correlation estimates between these traits were obtained by Wang et al. (1991), Rance et al. (2002), and Gaya et al. (2006). Peertile et al. (2014) reported a positive and high $(r=0.95)$ genetic correlation between BW at the age of 38 days and carcass weight in broiler chickens. In contrast, Zerehdaran et al. (2004) reported that the genetic correlation value $(0.22)$ between $\mathrm{BW}$ at 7 weeks and carcass percentage in broiler chickens was positive. As similar, Xu et al. (2011) confirmed the same results with a high value of genetic correlation (0.85). This suggested that using BW as a selection criterion could increase the carcass percentage, which might positively increase the production profit from these strains.

Body dimension traits played an important role in predicting the carcass weight of a chicken. In the current study, the genetic correlation estimates between carcass percentage with shank length, keel length, and body circumference were $0.46,0.62$, and 0.71 , respectively (Table 4). These results were similar to those of Tyasi et al. (2018), who reported that the genetic correlations between carcass percentage and body circumference, as well as carcass percentage and shank length, were 0.56 and 0.48 , respectively. This revealed the importance of selection for higher body diameter and body length to increase the carcass percentage of chickens.

The phenotypic correlations of carcass percentage with $\mathrm{BW}$ and $\mathrm{BD}$ traits were positive and low or moderate (0.11-0.42; Table 5). A significant positive genetic correlation between these traits was desirable in a breeding program since the selection of one trait improves the performance of other traits as a correlated response (Ullengala et al., 2020).

The present study revealed that the genetic correlation estimates between BW and CT were low or moderate, except for the genetic correlation estimate of BW16 with liver, heart, and leg (Table 4). This indicated that these traits would react indirectly to the direct selection to increase BW. Similar genetic correlation estimates between these traits were obtained by Venturini et al. (2014). The genetic correlation estimates ranged from 0.12 between BW0 and liver to 0.68 between BW16 and leg (Table 4). Gaya et al. (2006) reported that the genetic correlation estimates were $0.28,0.43$, and 0.21 between $\mathrm{BW}$ and heart, $\mathrm{BW}$ and liver, and $\mathrm{BW}$ and 
gizzard, respectively. Kause et al. (2012) found a genetic correlation estimate of 0.12 between $\mathrm{BW}$ at 14 days of age and the heart percentage. Ojedapo et al. (2008) reported that the correlation between live weight and leg weight was positive (0.93).

In the current study, the genetic correlation estimates between $\mathrm{BD}$ and $\mathrm{CT}$ were positive and low to moderate, ranged from 0.16 between keel length and head to 0.53 between body circumference and leg (Table 4). The current findings provided positive and moderate genetic correlation estimates (ranged 0.39-0.53) between leg and $\mathrm{BD}$ traits. Therefore, direct selection for $\mathrm{BD}$ would increase carcass traits. A small increase in gizzard, heart, and head by direct selection for shank length, keel length, and body circumference also appeared to be possible based on the genetic correlation estimate between these traits in the 0.16 to 0.32 range (Table 4). Phenotypically, in the current study, BW traits and BD correlated positively with the carcass traits in the range from low to moderate $(0.07-0.31)$ as presented in Table 5 .

\section{CONCLUSION}

In the present investigation, four Egyptian dual-purpose strains of chickens (Mandarah, Matrouh, Inshas and Silver Montazah) in terms of body weight, body dimensions, and carcass traits were characterized as essential economic traits in the poultry industry sector. The genetic estimations of these productive traits may provide useful information in determining a successful breeding strategy. Incorporating body dimension and weight as selection criteria in breeding programs will significantly increase the carcass percentage, and potentially improve the production benefit of the strains. Owing to positive genetic associations between body weight, body dimension, and carcass traits, assessing body weight and body dimension at a young age may be a fair and reliable predictor of carcass traits in future selection programs.

\section{DECLARATIONS}

\section{Acknowledgements}

Thanks to Scientific Research Fund (SRF), Benha University for funding this work.

\section{Competing interests}

The authors have declared that no competing interest exists.

\section{Funding}

This work was funded by the project "Whole transcriptome analysis of six Egyptian chicken strains; comparative genomic approaches," Code (M6/4/2), Scientific Research Fund (SRF), Benha University, Egypt.

\section{Ethical considerations}

Ethical issues (Including plagiarism, consent to publish, misconduct, data fabrication and/or falsification, double publication and/or submission, and redundancy) have been checked by the authors.

\section{Author contributions}

Mahmoud El-Attrouny and Mahmoud Iraqi designed the research project. Mahmoud El-Attrouny and Shereen Mohamed performed the experiment and collected data. Mahmoud El-Attrouny and Mahmoud Iraqi analyzed the data and interpreted the results. Mahmoud El-Attrouny and Shereen Mohamed wrote the initial manuscript. The authors revised the manuscript together and prepared it for publication.

\section{REFERENCES}

Abd El-karim R and Ashour AF (2014). Effect of selection for body weight on body measurements and carcass traits in ElSalam strain of chicken in Egypt. Journal of Animal and Poultry Production, Mansoura University, 5: 459- 471. DOI: https://doi.org/10.21608/JAPPMU.2014.70609

Abou El-Ghar RS and El-Karim R (2016). Effect of early selection for body weight, keel length, and breast circumference on egg production traits in inshas strain of chickens. Egyptian Poultry Science Journal, 36(2): 375-387. DOI: $\underline{\text { https://doi.org/10.21608/EPSJ.2016.5419 }}$

Adebambo AO, Ozoje MO, Adebambo F and Abiola SS (2006). Genetic variations in growth performance of Giriraja, Indian White Leghorn and improved indigenous chicken breeds in south west Nigeria. Nigerian Journal of Genetics, 20: 7-16. DOI: https://doi.org/10.4314/njg.v20i1.42247

Adeogun IO and Adeoye AA (2004). Heritabilities and phenotypic correlations of growth performance traits in Japanese quails. Livestock Research for Rural Development, 16(12):102-106. Available at: http://lrrd.cipav.org.co/lrrd16/12/adeo16103.htm

Adeyemi, KD (2021). Comparative effect of dietary Morinda lucida leaf and Butylated hydroxyanisole (BHA) on carcass traits, meat quality, and oxidative stability of broiler chickens. Journal of Food Science and Technology, 1-11. DOI: https://doi.org/10.1007/s13197-020-04916-2

Ahsan, M, Li X, Lundberg AE, Kierczak M, Siegel PB, Carlborg $\ddot{O}$ and Marklund S (2013). Identification of candidate genes and mutations in QTL regions for chicken growth using bioinformatic analysis of NGS and SNP-chip data. Frontiers in genetics, 4,226. Doi: https://doi.org/10.3389/fgene.2013.00226

Aslam ML, Bastiaansen JW, Crooijmans RP, Ducro BJ, Vereijken A, Groenen MA (2011). Genetic variances, heritabilities and maternal effects on body weight, breast meat yield, meat quality traits and the shape of the growth 
curve in turkey birds. BMC genetics, 12(1): 1-9. Available at: http://www.biomedcentral.com/1471-2156/12/14

Bungsrisawat P, Tumwasorn S, Loongyai W, Nakthong S and Sopannarath P ( 2018). Genetic parameters of some carcass and meat quality traits in Betong chicken (KU line). Agriculture and Natural Resources. 52(3): 274-279. Doi: https://doi.org/10.1016/j.anres.2018.09.010

Cahaner A and Nitsan Z (1985). Evaluation of simultaneous selection for live body weight and against abdominal fat in broilers. Poultry Science. 64(7): 1257-1263. https://doi.org/10.3382/ps.0641257

Chabault M, Baéza E, Gigaud V, Chartrin P, Chapuis H, Boulay M, Arnould C, D'Abbadie F, Berri C and Le Bihan-Duval E (2012). Analysis of a slow-growing line reveals wide genetic variability of carcass and meat quality-related traits. BMC genetics, 13(1): 1-8. Available at: http://www.biomedcentral.com/1471-2156/13/90

Chu TT, Madsen P, Norberg E, Wang L, Marois D, Henshall J and Jensen J (2020). Genetic analysis on body weight at different ages in broiler chicken raised in commercial environment. Journal of Animal Breeding and Genetics, 137(2): 245-259. DOI: https://doi.org/10.1111/jbg. 12448

Das AK, Kumar S and Rahim A (2015). Genetics of body conformation and feed efficiency characteristics in a control line of Rhode Island Red chicken. Iranian Journal of Applied Animal Science, 5(4): 965-973. Available at: http://www.iaujournals.ir/article_516636.html

Debes AA (2017). Effect of crossing between lohman selected leghorn with two develeped strains of chickens for improving some egg production traits. Egypt. Egyptian Poultry Science Journal, 37(4): 1261-1271. Doi: https://doi.org/10.21608/epsj.2017.5652

Duncan DB (1955). Multiple range and multiple tests. Biometrics, 11:1-42. Available at: https://scholar.google.com/scholar?hl=en\&as_sdt=0\%2C5\& $\mathrm{q}=$ Dancan \%2CD.B.+\%281955\%29\&btnG=

Egena SSA, Ijaiya AT and Kolawole R (2014) An assessment of the relationship between body weight and body measurements of indigenous Nigeria chickens (Gallus gallus domesticus) using path coefficient analysis. Livestock Research for Rural Development. 26:29-33. Available at: http://lrrd.cipav.org.co/lrrd26/3/egen26051.htm

El-Attrouny MM, Iraqi MM, Khalil MH, and El-Moghazy GM (2017). Genetic and phenotypic evaluation of growth traits in selection experiment performed in synthesized Benha chickens. Annals of Agricultural Science, Moshtohor. 51(1):33-42. Available at: https://aasj.bu.edu.eg/upload/2017/5922c479768468.600080 $\underline{49 . p d f}$

El-Attrouny MM, Iraqi MM, Sabike II, Abdelatty AM, Moustafa MM and Badr OA (2020). Comparative evaluation of growth performance, carcass characteristics and timed series gene expression profile of GH and IGF-1 in two Egyptian indigenous chicken breeds versus Rhode Island Red. Journal of Animal Breeding and Genetics. Doi: https://doi.org/10.1111/jbg.12517

Eltanany M, Philipp U, Weigend S and Distl O 2011. Genetic diversity of ten Egyptian chicken strains using 29 microsatellite markers. Animal Genetics, 42: 666-669. https://doi.org/10.1111/j.1365-2052.2011.02185.x

Emmerson, D. (2003). Breeding objectives and selection strategies for broiler production. In: W.M. Muir and S.E. Aggrey (eds), Poultry Breeding, Genetics and Biotechnology, (CAB International, UK), 113-126. Available at: Doi: http://dx.doi.org/10.1079/9780851996608.0113

Falconer DS and Mackay FC (1996). Introduction to quantitative genetics. Fourth edition. Longman Group, Harlow, Essex, England.108-183. Available at: https://www.worldcat.org/title/introduction-to-quantitativegenetics/oclc/422852955

Food and Agriculture Organization (FAO) (2005). Food and Agriculture Indicators Country: Egypt / Prepared by ESSA October 2005. Available at: http://www.fao.org/ES/ess/compendium 2005/pdf/ESS EG $\underline{\mathrm{Y}}$.

Food and Agriculture Organization (FAO) (2012). The State of Food and Agriculture: Investing in Agriculture for a Better Future. Food and Agriculture Organization of the United Nations (FAO), Rome, Italy. Available at: http://www.fao.org/3/i3028e/i3028e00.htm

Felício AM, Gaya LG, Ferraz JBS, Moncau CT, Mattos EC, Santos NP, Michelan Filho T, Balieiro JCC and Eler JP (2013). Heritability and genetic correlation estimates for performance, meat quality and quantitative skeletal muscle fiber traits in broiler. Livestock Science, 157(1):81-87. DOI: https://doi.org/10.1016/j.livsci.2013.08.005

Gaya LDG, Mourão GB, Ferraz JBS, Mattos ECD, Costa AM, Michelan Filho T, Rosa AF, Felício AM and Eler JP (2011). Estimates of heritability and genetic correlations for meat quality traits in broilers. Scientia Agricola, 68(6): 620-625. DOI: https://doi.org/10.1590/S0103-90162011000600002

Gaya LG, Ferraz JBS, Rezende FM, Mourao GB, Mattos EC, Eler JP and Michelan Filho T (2006). Heritability and genetic correlation estimates for performance and carcass and body composition traits in a male broiler line. Poultry Science, $\quad 85(5)$ : 837-843. https://doi.org/10.1093/ps/85.5.837

Grosso JL, Balieiro JC, Eler JP, Ferraz JB, Mattos EC and Michelan Filho T (2010). Comparison of different models to estimate genetic parameters for carcass traits in a commercial broiler line. Genetics and Molecular Research, 9(2): 908-918. DOI: https://doi.org/10.4238/vol9-2gmr773

Haunshi S, Shanmugam M, Padhi MK, Niranjan M, Rajkuma U, Reddy MR and Panda AK (2012). Evaluation of two Indian native chicken breeds for reproduction traits and heritability of juvenile growth traits. Tropical Animal Health and Production, 44(5): 969-973. DOI: https://doi.org/10.1007/s11250-011-9994-y

Hermiz HN and Abdullah MS (2020). Genetic and nongenetic parameters for body weights of two Iraqi local chickens. The Iraqi Journal of Agricultural Science, 51(1): 323-332. DOI: https://doi.org/10.36103/ijas.v51i1.931

Hosny F (2006). Poultry sector country review, Egypt. FAO animal production and health division. Emergency centre for transboundary animal diseases socio economics, production and biodiversity unit. Available at: http://www.fao.org/3/ai355e/ai355e.pdf 
Ige A O (2013). Relationship between body weight and growth traits of crossbred fulani ecotype chicken in derived savannah zone of Nigeria. International Journal of Applied Agriculture and Apiculture Research, 9:157-166. Available at: $\quad$ file:///C:/Users/orgnal/Downloads/96943Article\%20Text-252429-1-10-20131114\%20(5).pdf

Iraqi MM, Hanafi MS, Khalil MH, El-Labban AFM, and Ell-Sisy $M$ (2002). Genetic evaluation of growth traits in a crossbreeding experiment involving two local strains of chickens using multi-trait animal model. Livestock Research for Rural Development, 14(5): 2002. Available at: http://www.lrrd.org/lrrd14/5/iraq145tmp.htm

Jambui M, Honaker CF and Siegel PB (2017). Selection for juvenile body weight in chickens: Standardizing for scaling. Poultry Science, 96(8): 2562-2568. DOI: https://doi.org/10.3382/ps/pex080

Johansson AM, Pettersson ME, Siegel PB and Carlborg Ö (2010). Genome-wide effects of long-term divergent selection. PLoS Genet. 6(11), 1001188. Available at: DOI: https://doi.org/10.1371/journal.pgen.1001188

Johnson DL and Thompson R (1995). Restricted maximum likelihood estimation of variance components for univariate animal models using sparse matrix techniques and average information. Journal of dairy science, 78: 449-456. DOI: http://dx.doi.org/10.3168\%2Fjds.S0022-0302(95)76654-1

Kause A, van Dalen S and Bovenhuis H (2012). Genetics of ascites resistance and tolerance in chicken: A random regression approach. G3: Genes| Genomes| Genetics, 2(5), 527-535. DOI: https://doi.org/10.1534/g3.112.002311

Khalid AM, Yousif IA, Omer MI, and Elamin KM (2012). Genetic variability of body composition traits in Sudanese Native large Beladi Chicken. Agriculture and Biology Journal of North America, 3(2): 69-76. http://dx.doi.org/10.5251/abjna.2012.3.2.69.76

Kosba MA and Abd El-Halim HAH (2008). Evaluation of the Egyptian local strains of chickens. Egyptian Poultry Science Journal, 28: 1239-1251. Available at: https://citeseerx.ist.psu.edu/viewdoc/download?doi=10.1.1.6 09.1932\&rep=rep1\&type $=$ pdf

Le Bihan-Duval E, Berri C, Baeza E, Millet N and Beaumont C (2001). Estimation of the genetic parameters of meat characteristics and of their genetic correlations with growth and body composition in an experimental broiler line. Poultry Science, $80(7)$ : 839-843. DOI: https://doi.org/10.1093/ps/80.7.839

Le Bihan-Duval E, Debut M, Berri CM, Sellier N, SantéLhoutellier V, Jégo Y and Beaumont C (2008). Chicken meat quality: genetic variability and relationship with growth and muscle characteristics. BMC Genetics, 9(1):1-6. DOI: https://doi.org/10.1186/1471-2156-9-53

Le Bihan-Duval E, Mignon-Grasteau S, Millet N and Beaumont C (1998). Genetic analysis of a selection experiment on increased body weight and breast muscle weight as well as on limited abdominal fat weight. British Poultry Science, 39(3): 346-353. DOI: https://doi.org/10.1080/00071669888881

Meyer K (2012). WOMBAT Version 1.0 a program for Mixed Model Analyses by Restricted Maximum Likelihood: User notes. Animal Genetics and Breeding Unit, Armidale, 103p. Available at: https://core.ac.uk/display/21716827
Niknafs S, Javaremi AN, Yeganch HM and Fatemi SA (2012). Estimation of genetic parameters for body weight and production traits in Mazandaran native chicken. Tropical animal health and production, 44: 1437-1443. DOI: https://doi.org/10.1007/s11250-012-0084-6

Norris D, Banga C, Benyi K and Sithole BC (2004). Estimation of genetic parameters and variance components for growth traits of Nguni cattle in Limpopo Province, South Africa. Tropical animal health and production, 36(8): 801806. Available https://doi.org/10.1023/b:trop.0000045966.59590.96

National Research Council (NRC) (1994). National Research Council Nutrient Requirement of Poultry. Ninth Revised Ed. National Academy Press Washington DC, USA. Available at: https://www.nap.edu/catalog/2114/nutrient-requirementsof-poultry-ninth-revised-edition-1994

Nunes BD, Ramos SB, Savegnago RP, Ledur MC, Nones K, Klein CH and Munari DP (2011). Genetic parameters for body weight, carcass chemical composition and yield in a broiler-layer cross developed for QTL mapping. Genetics and molecular biology, 34(3): 429-434. DOI: https://doi.org/10.1590/s1415-47572011005000019

Ojedapo LO, Akinokun O, Adedeji TA, Olayeni TB, Ameen SA and Amao SR (2008). Effect of Strain and carcass characteristics of three commercial broilers reared in deep litter system in the Derived Savannah area of Niger. World Journal of Agricultural Sciences. 4(4): 487491. Available https://www.idosi.org/wjas/wjas4(4)/14.pdf

Padhi MK, Chatterjee RN, Rajkumar U, Bhattacharya TK, and Bhanja SK (2015). Genetic and phenotypic parameters estimates for body weight, conformation, production and reproduction traits of PD1 (Vanaraja male line) during different periods. Indian Journal of Animal Science, 85: 883$888 . \quad$ Available at: https://www.researchgate.net/publication/281114221_Geneti c_and_phenotypic_parameters_estimates_for_body_weight conformation_production_and_reproduction_traits_of_PD1_ Vanaraja_male_line_during_different_periods

Peertile SF, Zampar A, Petrini J, Gaya LD, Rovadoscki GA, Ramírez-Díaz J, Ferraz JB, Michelan Filho T and Mourão GB (2014). Correlated responses and genetic parameters for performance and carcass traits in a broiler line. Revista Brasileira de Saúde e Produção Animal, 15(4): 1006-1016. DOI: https://doi.org/10.1590/S1519-99402014000400008

Prado-Gonzalez EA, Ramirez-Avila L and Segura-Correa JC (2003). Genetic parameters for body weights of Creole chickens from Southeastern Mexico using an animal model. Livestock Research for Rural Development, 15(1): 27-31. Available https://lrrd.cipav.org.co/lrrd15/1/prad151.htm

Rajkumar U, Rajaravindra KS, Haunshi S, Niranjan M, Bhattacharya TK, and Chatterjee RN (2012). Genetic architecture of growth and production parameters in a laying cycle of 72 weeks in naked neck chickens. Indian Journal of Animal Sciences, 82: 615-619. Available at: https://scholar.google.com/scholar?cluster $=26216455777887$ 6963\&hl=en\&as_sdt=0,5

Ramadan S, Kayang BB, Inoue E, Nirasawa K, Hayakawa H, Ito $\mathrm{Si}$ and Inoue-Murayama M (2012). Evaluation of genetic diversity and conservation priorities for Egyptian chickens. 
Open Journal of Animal Sciences, 2: 183-190. DOI: http://dx.doi.org/10.4236/ojas.2012.23025

Rance KA, McEntee GM, and McDevitt RM (2002). Genetic and phenotypic relationships between and within support and demand tissues in a single line of broiler chicken. British Poultry Science, 43(4): 518-527. DOI: https://doi.org/10.1080/0007166022000004426

Randazzo B, Zarantoniello M, Cardinaletti G, Cerri R, Giorgini E, Belloni A, Contò M, Tibaldi E and Olivotto I (2021). Hermetia illucens and Poultry by-Product Meals as Alternatives to Plant Protein Sources in Gilthead Seabream (Sparus aurata) Diet: A Multidisciplinary Study on Fish Gut Status. Animals, 11(3): $677 . \quad$ DOI: https://doi.org/10.3390/ani11030677

Rayan GN, El-Faham AI and Ibrahim SA (2017). Testing heterotic effect and strain differences for carcass traits of some developed local strains of chicken and their crosses. Egyptian Poultry Science Journal, 37(4); 10471061. DOI: https://doi.org/10.21608/epsj.2017.5379

Resende RO, Martins EN, Georg PC, Paiva E, Conti AC, Santos AI, Sakaguti ES and Murakami AE (2005). Variance components for body weight in Japanese quails (Coturnix japonica). Brazilian Journal of Poultry Science, 7(1): 23-25. DOI: http://dx.doi.org/10.1590/S1516-635X2005000100004

Salvian M, Moreira GC, Reis ÂP, Dauria BD, Pilonetto F, Gervásio IC, Ledur MC, Coutinho LL, Spangler ML and Mourão GB (2020). Estimation of Breeding Values Using Different Densities of Snp to Inform Kinship in Broiler Chickens. DOI: https://doi.org/10.21203/rs.3.rs-32429/v1

SAS 2004. SAS User's Guide: version 9.1. SAS Institute, North Caroline 5136.

Saxena VK and Kolluri G (2018). Selection Methods in Poultry Breeding: From Genetics to Genomics. Application of Genetics and Genomics in Poultry Science, 19-32. DOI: http://dx.doi.org/10.5772/intechopen.77966

Singh CB and Jilani MH (2005). Inheritance of growth and confirmation traits in CARI-Devendra poultry strain. Indian Journal of Poultry Science. 40 (1): 67-69. Available at: https://www.indianjournals.com/ijor.aspx?target=ijor:ijps\&v $\underline{\text { olume }}=40 \&$ issue $=1 \&$ article $=015$
Thiruvenkadan AK, Prabakaran R and Panneerselvam S (2011). Broiler breeding strategies over the decades: an overview. World's Poultry Science Journal, 67(2): 309-336. DOI: https://doi.org/10.1017/S0043933911000328

Tongsiri S, Jeyaruban GM, Hermesch S, van der Werf JH, Li L and Chormai T (2019). Genetic parameters and inbreeding effects for production traits of Thai native chickens. AsianAustralasian journal of animal sciences, 32(7): 930-938. DOI: https://dx.doi.org/10.5713\%2Fajas.18.0690

Tyasi TL, Qin N, Niu X, Sun X, Chen X, Zhu H, Zhang F and Xu R (2018). Prediction of carcass weight from body measurement traits of Chinese indigenous Dagu male chickens using path coefficient analysis. Indian Journal of Animal Science, 88(6): 744-748. Available at: https://www.scopus.com/record/display.uri?eid=2-s2.0$\underline{85049574840 \& \text { origin }=\text { inward\&txGid=caa3891287ed } 191397}$ 7ecb3a866fd5d8

Ullengala R, Prince LL, Paswan C, Haunshi S, and Chatterjee R (2020). Variance component analysis of growth and production traits in Vanaraja male line chicken using animal model. Asian-Australasian journal of animal sciences, 34(4): 471-481. DOI: https://doi.org/10.5713/ajas.19.0826

Venturini GC, da CRUZ VA, Rosa JO, Baldi F, El Faro L, Ledur MC, Peixoto JD and Munari DP (2014). Genetic and phenotypic parameters of carcass and organ traits of broiler chickens. Genetics and Molecular Research, 13(4): 1029410300. DOI: https://doi.org/10.4238/2014.december.4.24

Wang L, McMillan I and Chambers JR (1991). Genetic correlations among growth, feed, and carcass traits of broiler sire and dam populations. Poultry Science, 70(4): 719-725. DOI: https://doi.org/10.3382/ps.0700719

Xu TS, Liu XL, Huang W, and Hou SS (2011). Estimates of genetic parameters for body weight and carcass composition in Pekin ducks. Journal of animal and veterinary advances, 10: 23-28. DOI: http://dx.doi.org/10.3923/javaa.2011.23.28

Zerehdaran SA, Vereijken AJ, Van Arendonk JA and Van der Waaijt EH (2004). Estimation of genetic parameters for fat deposition and carcass traits in broilers. Poultry Science, 83(4): 521-525. DOI: https://doi.org/10.1093/ps/83.4.521 